pp. $51-62$

\title{
Joanna SZCZYRBA-POROSZEWSKA
}

ORCID: 0000-0003-1740-2113

Uniwersytet Pedagogiczny im. KEN

w Krakowie

\section{Monika SEMIK}

ORCID: 0000-0002-3832-9085

Uniwersytet Pedagogiczny im. KEN

w Krakowie

\section{Odpowiedzialność nauczyciela edukacji przedszkolnej i wczesnoszkolnej w zakresie edukacji muzycznej}

\begin{abstract}
Responsibility of the Teacher of Preschool and Early School Education Teacher in the Field of Music Education

In contemporary pedagogical discourse, a lot of attention is paid to the teacher - he is largely responsible not only for the level of his musical competences, but above all for the multidirectional development of the child in the period of development, which is characterized by a particular sensitivity to external stimulation. This article presents the determinants of a teacher's responsibility in terms of knowledge of a child's musical development and the current core curriculum. The results of the survey conducted among 47 PIE students innvestigated their perception of preschool and early school education teacher's responsibility in the field of music education. The results of the study showed that the respondents are aware of the teacher's responsibility in the field of music education and associate it with important issues distinguished by methodologists, among others with developing positive attitudes and interests in children.
\end{abstract}

Keywords: teacher's responsibility, preschool education, early school education, music education

Słowa kluczowe: odpowiedzialność nauczyciela, edukacja przedszkolna, edukacja wczesnoszkolna, edukacja muzyczna

We współczesnym dyskursie pedagogicznym wiele uwagi poświęca się nauczycielowi - jest on w dużej mierze odpowiedzialny nie tylko za poziom swoich muzycznych kompetencji merytorycznych, metodycznych i wychowawczych ${ }^{1}$,

\footnotetext{
${ }^{1}$ Podział kompetencji przyjęty za: Taraszkiewicz, 2001, s. 75.
} 
ale przede wszystkim za wielokierunkowy rozwój dziecka w okresie rozwoju cechującym się szczególną wrażliwością na zewnętrzną stymulację. Takie rozumienie odpowiedzialności nauczyciela łączy się z ogólnym rozumieniem tego pojęcia definiowanego jako: „1. «obowiązek moralny lub prawny odpowiadania za swoje lub czyjeś czyny»; 2. "przyjęcie na siebie obowiązku zadbania o kogoś lub o coś»" 2 . W kontekście pracy z dziećmi w wieku przedszkolnym i wczesnoszkolnym istotne obszary odpowiedzialności nauczyciela wyznaczają psychologiczne prawidłowości rozwoju muzycznego dziecka, a także dokumenty regulujące proces edukacji (por. Rozporządzenie, 2017).

\section{Odpowiedzialność wynikająca ze znajomości psychologicznych prawidłowości rozwoju muzycznego dziecka do lat 10}

Znajomość psychologicznych prawidłowości rozwoju muzycznego dziecka do lat 10 pozwala docenić rangę otoczenia muzycznego, za które odpowiedzialna jest w pierwszej kolejności rodzina, a następnie instytucje edukacyjno-oświatowej (tj. przedszkola i szkoły podstawowe). Jak wskazują naukowcy (m.in.: E. Szubertowska (2002, s. 82-86), E. Frołowicz (2012, s. 372), B. Bonna (2016, s. 325-330), P. A. Trzos (2018, s. 387-389)), tylko niewielka część polskich rodzin w sposób właściwy stymuluje i wspiera rozwój muzyczny dziecka i dlatego na powszechnej edukacji muzycznej spoczywa doniosła odpowiedzialność w tym zakresie.

Muzyka oraz mowa towarzyszą dziecku od początku jego życia. Już w okresie prenatalnym reaguje ono na dźwięki z otoczenia, a jako niemowlę - odwraca głowę w kierunku głosu matki. Interesuje się wypowiadanymi przez nią słowami czy śpiewanymi kołysankami. Pierwszy rytm, który słyszy dziecko, to rytm serca matki, pierwszą muzyką jest natomiast kontur intonacyjny melodii jej mowy. Mowa oraz ekspresja muzyczna uznawane są za wrodzone zdolności człowieka, a ich uniwersalność przejawia się w tym, że wszystkie kultury świata wyrażają siebie przez ekspresję werbalną oraz muzyczną. Ponadto zarówno muzyka, jak i język rozwijają się dzięki interakcjom (Bogdanowicz, 2001, s. 30). Można zauważyć je w spontaniczności działania oraz twórczości dzieci już na etapie przedszkola.

Warto podkreślić, że najistotniejsze z punktu widzenia psychologii momenty wrażliwości na muzykę przypadają na okres edukacji przedszkolnej i wczesnoszkolnej. Według E. E. Gordona „każde dziecko rodzi się z jakimś poziomem uzdolnień muzycznych" - 68\% noworodków ma przeciętne uzdolnienia, $16 \%$ - wyższe od przeciętnych, $16 \%$ ma uzdolnienia niższe od przeciętnych

\footnotetext{
${ }^{2}$ https://sjp.pwn.pl/sjp/;2493511
} 
(Gordon, 1997, s. 13-14). Aby jednak w pełni rozwinąć te uzdolnienia, konieczne jest odpowiednie środowisko muzyczne. Według Gordona dziecko „musi doświadczać bogatych i różnorodnych prezentacji muzycznych zanim ukończy osiemnasty miesiąc życia, aby w późniejszym nieco wieku rozwinąć potrzebną do nauki gotowość" (s. 9). Kolejnym kluczowym momentem rozwoju jest dziewiąty rok życia dziecka: „wpływ bogatego muzycznie środowiska na uzdolnienia muzyczne zmniejsza się wraz z upływem czasu. [...] W okresie, gdy dziecko zbliży się do dziewiątego roku życia, poziom jego muzycznych uzdolnień nie będzie już dłużej warunkowany przez środowisko, nawet jeśli wtedy będzie ono nadzwyczaj sprzyjające" (s. 14).

Szczegółowe wyznaczniki rozwoju muzycznego dzieci do lat 10 przybliżają Z. Burowska i B. Głowacka (2006, s. 21-23):

- W zakresie realizacji melodii dzieci posiadają łatwość intonowania melodii w obrębie tretrachordu komórki kwartowej (sol-mi-la), początkowo śpiewają tylko kilka dźwięków prawidłowo (3-5 rok życia), z czasem reprodukują ogólny kontur melodii przy niestabilnej intonacji (5-6 rok życia), następnie melodia odtwarzana jest poprawnie poza nielicznymi fałszami (śpiewanie interwałowe 6-9 rok życia).

- W zakresie rytmu dzieci początkowo podejmują próby udziału w zabawach muzycznych związanych z ruchem, słowem, rozróżniają proste wzory rytmiczne, eksplorują możliwości wykonywania rytmów na instrumentach, preferują wartości krótkie, z czasem wzrasta precyzja w wykonywaniu rytmów, a także koordynacja muzyczno-ruchowa (do 7 roku życia).

- W zakresie dynamiki dzieci początkowo preferują głośne utwory, następnie wzrasta wrażliwość na niuanse dynamiczne (pojmowanie crescenda, diminuenda, sforzata, oraz umiejętność wyrażania tych zmian ruchem (2-5 rok życia), co prowadzi do przyswojenia pojęć dynamicznych, umiejętności ich rozpoznawania i ruchowej realizacji.

- W zakresie barwy początkowo preferują brzmienie wyraziste, jaskrawe (3-7 rok życia), na bazie doświadczeń możliwe jest przyswojenie barw różnych instrumentów.

- W zakresie tempa dzieci preferują tempo szybsze, podejmują próby oceny i rozpoznawania tempa $\mathrm{w}$ muzyce, $\mathrm{z}$ czasem wzrasta synchronizacja ruchów ze zmieniającym się tempem muzyki (4-7 rok życia) (tamże).

Z punktu widzenia psychologii muzyki w procesie edukacji muzycznej nie można poprzestać na odtwarzaniu muzyki. Szczególnie istotne jest zachęcanie do spontanicznego muzycznego eksperymentowania w okresie przedszkolnym. Według J. Slobody, jeżeli dziecko nie będzie w sposób szczególny do tego zachęcane, jego potencjał twórczy w tym zakresie może zanikać już po piątym roku życia na korzyść rozwijającej się dokładności odtwórczej (2002, s. 251). Tego typu działania są dosyć rzadko podejmowane w zakresie edukacji muzycznej. W. A. Sacher uważa, że tworzenie muzyki jest najrzadziej podejmowaną aktywnością muzyczną (2012, s. 190) ze względu na niski poziom kompetencji muzycznych nauczycieli. Tymczasem J. Sloboda dopatruje się przyczyny takiego stanu rzeczy w uwarunkowaniach kulturowych: 
W kulturze euro-amerykańskiej nie stwarza się zbyt wiele okazji do improwizacji, ale szczególną wartość przypisuje się poprawnemu reprodukowaniu dobrze znanych utworów, np. śpiewanie hymnów, piosenek kibiców sportowych, uczęszczanie na koncerty muzyki poważnej. [...]. W naszej kulturze kompozytorzy i improwizatorzy nie wywodzą się spośród osób, których doświadczenie muzyczne opierało się na zwykłej akulturacji - ich umiejętności wynikają ze specyficznego i kulturowo nietypowego wsparcia i treningu (2002, s. 251).

Zdaniem R. Patzlaffa „dzieci czują się w swoim żywiole wszędzie tam, gdzie w jedną całość splatają się śpiew i zabawa, mówienie i ruch. I dlatego dzieci mają rację, domagając się powtarzania wciąż od nowa piosenek i wyliczanek, wierszyków i zabaw z korowodami. Nie chodzi o informację wyrażającą się w pojęciach (wówczas wystarczyłaby jednorazowa wypowiedź). Dla dzieci ważna jest działająca w strumieniu czasu formująca, kształtotwórcza siła muzyczna słowa, bo we współbrzmieniu $z$ tą muzyką budują własny organizm. Mowa żyje w dziecku dzięki rytmicznemu powtarzaniu, tak samo jak ciało fizyczne żyje dzięki rytmicznie powtarzanym czynnościom jedzenia i picia. Dzieci nawet samodzielnie wymyślają różne kompozycje głosek, których jedynym celem jest radość płynąca z rytmu i z tego, co w słowach śpiewa” (2008, s. 116).

Różnorodne wyliczanki i zabawy ruchowe dawniej powstawały wśród dzieci spontanicznie. We współczesnym świecie odpowiedzialność za wspieranie muzykalności młodych ludzi należy do rodziców i wychowawców, których zadaniem jest zachęcanie do odtwarzania oraz tworzenia rymowanek i śpiewanek ze świadomością ich dobroczynnego działania. Kolejną kwestią jest literatura dla dzieci, w której wyborze powinno się kierować muzyczno-rytmiczną jakością mowy, obrazowością słów czy artystyczną kompozycją zdań.

\footnotetext{
Być może trzeba na nowo odkryć w sobie dziecko, aby poczuć entuzjazm dla muzycznej jakości poetycko ukształtowanej mowy i doświadczyć na własnym ciele jej uzdrawiającej i pobudzającej do rozwoju siły. Dopiero wtedy można poczuć, co to znaczy przebywać w regionach tworzących i kształtujących cielesność sił życiowych, w regionach, w których dziecko jest zadomowione całą swoją istotą (tamże).
}

Istotnym momentem dla dziecka jest rozpoczęcie edukacji w pierwszej klasie szkoły podstawowej. Nauczyciel pracujący z dziećmi w wieku wczesnoszkolnym powinien pamiętać, że w zakresie edukacji muzycznej nie wszystkie dzieci uzyskały gotowość do realizacji podstawowych zadań muzycznych. Przyczyn tej sytuacji nie należy łączyć z niskim poziomem uzdolnień dziecka, ale z małą liczbą i różnorodnością doświadczeń muzycznych. Kwestię tę akcentuje Gordon:

Niestety większość dzieci, które przychodzą do szkoły w wieku pięciu czy sześciu lat, nie otrzymywała wcześniej dostatecznej stymulacji muzycznej, aby mogła z powodzeniem włączyć się w formalną muzyczną edukację. Przeciętne dziecko nie było zwykle należycie kierowane muzycznie (ani w sposób nieustrukturowany, ani ustrukturowany), nie jest więc w stanie podołać 
oczekiwaniom związanym z prawidłowym śpiewaniem i poruszaniem się przy muzyce (1997, s. 97).

Nauczyciel powinien zatem dostarczać dzieciom bogatych doświadczeń muzycznych, tak by ich start szkolny łączył się z przyjemnymi skojarzeniami i możliwością odczuwania małych sukcesów w edukacji muzycznej.

\section{Odpowiedzialność w zakresie realizacji założeń i treści podstawy programowej dla przedszkoli i klas I-III}

W tradycyinie pojmowanym procesie powszechnej edukacji muzycznej dzieci doświadczają muzyki przez takie aktywności, jak śpiew, gra na instrumentach, słuchanie muzyki, tworzenie muzyki, ruch, a także przez integrację muzyki z innymi dziedzinami sztuki (Przychodzińska, Lipska, 1991). Odpowiedzialność nauczyciela polega zatem na realizowaniu urozmaiconych działań, dla których osnowę stanowi podstawa programowa dla wychowania przedszkolnego i edukacji wczesnoszkolnej.

Za podstawową i zarazem najważniejszą formę aktywności muzycznej dziecka na etapie edukacji przedszkolnej uważa się śpiew. Nic więc dziwnego, że w repertuarze przedszkola znajdują się piosenki dziecięce oraz utwory ludowe (Rozporządzenie, 2017, s. 6). W wieku przedszkolnym następuje wzmożony rozwój zdolności motorycznych i koordynacji ruchowej. Jest to również okres krytyczny dla rozwoju słuchu absolutnego (piąty i szósty rok życia) (Ławrowska, 2003, s. 16-17). Jest to więc doskonały czas na odpowiedzialne i świadome rozwijanie intonacji, którą wspomagać można dzięki metodzie i systemowi C. Orffa, w którym proces kształcenia muzycznego przebiega analogicznie do procesów rozwojowych muzyki, a więc rozpoczyna się od mowy rytmizowanej, nawoływań, okrzyków, zdań pytających i naśladowania odgłosów przyrody. Następnie wprowadza się dwa dźwięki oparte na tercji małej (kukanie kukułki), potem trychord komórki kwartowej i pentatonikę bezpółtonową. Orff podkreślał, że skala ta oddaje naturalny sposób myślenia dziecka w kulturze europejskiej nie i tylko (Wilk, 1989, s. 42).

Wiek przedszkolny jest istotnym czasem dla rozwoju muzycznego, wtedy właśnie dziecko wchodzi w świat muzyki przez zabawę, a uczestniczenie w niej staje się dla niego źródłem przyjemności. W tym czasie muzyka w naturalny sposób może, a nawet powinna, coraz częściej przyciągać na chwilę jego uwagę, co przejawia się w słuchaniu w bezruchu. Co istotne, nie musi to być muzyka wyłącznie dziecięca.

W klasach I-III jest także ważna aktywność głosowa. Najbardziej przystępną formą muzyczną dla dziecka jest piosenka: 
Jest to miniatura muzyczna, dostępna wykonawczo dla nie w pełni jeszcze ukształtowanego głosu, zawierająca proste treści słowno-muzyczne, które dziecko potrafi zrozumieć i przeżyć. Piosenka - łącząca muzykę ze słowem - ułatwia dziecku pierwsze kontakty z trudną dla niego, bo abstrakcyjną, sztuką dźwięków i jest dla dziecka podstawową formą muzycznej ekspresji (Przychodzińska, Lipska, 1991, s. 16).

W doborze piosenek należy się kierować nie tylko zgodnością tematyczną z realizowanym tematem, ale możliwościami wykonawczymi i percepcyjnymi dziecka. Repertuar wokalny powinien obejmować piosenki dziecięce (np.: Śpiewnik dla dzieci Z. Noskowskiego, Cztery pory roku, Piosenki dla dzieci W. Lutosławskiego), polskie pieśni ludowe (np.: Oj, zwiesna dokoła, Na tym dworskim moście, Świętego fana, Hej, bracia, czy śpicie), a także pieśni ludowe różnych narodów (Przychodzińska, Lipska, 1991, s. 16-71). W kontekście aktualnej podstawy programowej (Rozporządzenie, 2017, s. 45) warto uwzględnić utwory patriotyczne i historyczne, a także $z$ tekstem w języku obcym. Jak wskazuje obserwacja współczesnej rzeczywistości edukacyjnej, w pracy z piosenką najczęściej stosuje się naukę ze słuchu, a znacznie rzadziej uczenie z nut i za pomocą nut. Warto zachęcać dzieci do samodzielnego odczytywania wybranych fragmentów piosenek $z$ nut. Nieocenioną pomoc w zakresie odczytywania rytmu stanowią sylaby rytmiczne. Do poznawania nowych melodii piosenek warto stosować instrumenty: flet podłużny, flażolet, dzwonki, ksylofon.

Wiele wartości ma wspólne muzykowanie. W klasach I-III gra na instrumentach polega m.in. na realizacji efektów perkusyjnych (Przychodzińska, Lipska, 1991, s. 73-116), w których można wykorzystywać naturalne instrumenty (ręce i nogi). Efekty te mogą tworzyć akompaniament do wykonywanych piosenek. Warto stosować instrumenty perkusyjne o nieokreślonej wysokości dźwięku: bębenek jednostronny, tamburyn, talerze, trójkąt, kołatkę, marakasy, klawesyn, tarkę, blok akustyczny, a także o określonej wysokości dźwięku (dzwonki diatoniczne i chromatyczne) (tamże). W aktualnej podstawie programowej (Rozporządzenie, 2017, s. 45-46) uwzględniono nie tylko proste akompaniamenty do śpiewu, ale także realizacje tematów rytmicznych i melodycznych $z$ piosenek oraz utworów instrumentalnych.

$\mathrm{Z}$ potrzebą ruchu łączy się kolejna aktywność muzyczna, według M. Przychodzińskiej i E. Lipskiej polega ona m.in. na realizacji elementów zabaw i ćwiczeń muzyczno-ruchowych, które uwrażliwiają na takie elementy muzyki, jak rytm, dynamika, tempo, metrum, wysokość dźwięku. Dzieci szczególnie lubią:

- zabawy z piosenką;

- układy taneczne wykorzystujące elementy podstawowych figur tańców polskich (krakowiaka, kujawiaka, oberka i innych tańców regionalnych);

- interpretacje ruchowe utworów muzycznych (Przychodzińska, Lipska, 1991, s. 117-171). 
W aktualnej podstawie programowej (Rozporządzenie, 2017, s. 45) wyróżniono także cieszące się dużą popularnością tańce integracyjne i pląsy.

Postęp techniczny sprawił, że muzyka jest współcześnie dostępna za pośrednictwem multimediów, a od lat sześćdziesiątych ubiegłego wieku słuchanie muzyki zostało uwzględnione jako aktywność w klasach I-III (por. Kisiel, 2005). Ze względu na możliwości percepcyjne dzieci warto wybierać utwory krótkie, jedno-, dwuminutowe (por. Przychodzińska, Lipska, 1991, s. 218), lub wybrane fragmenty bardziej złożonych utworów wokalnych, wokalno-instrumentalnych, instrumentalnych. Jak pisze M. Przychodzińska, utworów można słuchać:

- analitycznie - uwaga dzieci skupiona jest na istotnych elementach dzieła muzycznego (nauczyciel ukierunkowuje uwagę dzieci za pomocą krótkich i konkretnych pytań);

— w sposób programowo-interpretujący — treść muzyczna jest interpretowana przez fabułę pozamuzyczną (np. układanie opowiadania dopasowanego do struktury muzyki, nadawanie utworom własnych tytułów, odgrywanie scenek, obserwowanie związków między tekstem a muzyką, wyrażanie muzyki za pomocą środków plastycznych (Przychodzińska, Lipska, 1991, s. 216-236).

W aktualnej podstawie programowej słuchanie muzyki jest łączone $\mathrm{z}$ aktywnością ruchową, gestami dźwiękotwórczymi oraz z towarzyszeniem prostych opracowań instrumentalnych (Rozporządzenie, 2017, s. 44-45).

W pracy z dziećmi klas I-III warto uwzględniać twórczą aktywność muzyczną. Według M. Przychodzińskiej „improwizacja muzyczna powinna być wtopiona w całość procesu dydaktycznego - zintegrowana $\mathrm{z}$ innymi formami wychowania muzycznego" (Przychodzińska, Lipska, s. 174). W aktualnej podstawie programowej (Rozporządzenie, 2017, s. 45-46) jest ona realizowana, zgodnie z postulatem Przychodzińskiej, w połączeniu z innymi aktywnościami muzycznymi. Przykładowo: dziecko tworzy melodie, schematy rytmiczne, improwizacje ruchowe, a także sekwencje i układy poruszania się do wybranych utworów (por. tamże).

Ogólnie przyjmuje się, że proces edukacji muzycznej w klasach I-III powinien koncentrować się na doświadczaniu muzyki, a wiedza teoretyczna powinna być ograniczona do minimum. W aktualnej podstawie programowej łączy się ona m.in. ze znajomością różnych form zapisu dźwięków (piktogramów, klocków rytmicznych, kolorów, liczb, obrazków), wykorzystywanych także w zabawie. Przez doświadczanie dzieci powinny poznać kluczowe określenia najważniejszych elementów muzyki, tj.: dźwięki wysokie - niskie (melodia); dźwięki długie — krótkie (rytm); dźwięki ciche — głośne (dynamika); sopran, bas, a także nazwy i brzmienie wybranych instrumentów muzycznych w zakresie barwy (tamże, s. 46). 


\section{Odpowiedzialność w nauczyciela w zakresie edukacji muzycznej w kontekście badań własnych}

Aby poznać, w jaki sposób postrzegana jest odpowiedzialność nauczyciela w zakresie edukacji muzycznej wśród przyszłych nauczycieli, objęto badaniem ankietowym 47 studentek pedagogiki przedszkolnej i wczesnoszkolnej (drugi rok studiów dziennych drugiego stopnia). Kwestionariusz ankiety elektronicznej został utworzony i udostępniony za pośrednictwem platformy MS Teams. Respondentki odpowiedziały na dwa pytania (jedno zamknięte i jedno otwarte). Dane uzyskane na podstawie odpowiedzi na pytania poddano elementarnej analizie ilościowej, a wyniki przedstawiono tabelarycznie. W pytaniu otwartym wypowiedzi respondentek poddano analizie jakościowej i wyodrębniono najczęściej powtarzające się kategorie dotyczące odpowiedzialności nauczyciela w zakresie edukacji muzycznej.

Wyniki badań prezentują tabele 1 i 2 .

Zdecydowana większość respondentek uważa, że nauczyciel edukacji przedszkolnej i wczesnoszkolnej ponosi wysoką (21 osób) i bardzo wysoką odpowiedzialność (14) w zakresie edukacji muzycznej (por. tabelę 1). Analiza jakościowa wykazała, że odpowiedzialność nauczyciela w zakresie edukacji muzycznej była najczęściej łączona $z$ takimi kategoriami, jak: rozwijanie zainteresowań i pozytywnych postaw wobec muzyki, przekazanie wiedzy z zakresu edukacji muzycznej, stymulowanie rozwoju muzycznego w okresie szczególnej podatności na oddziaływania muzyczne, rozwijanie umiejętności muzycznych, wprowadzenie w świat muzyki, kultury muzycznej, uwrażliwianie dzieci na muzykę.

Największa grupa respondentek łączyła odpowiedzialność nauczyciela edukacji przedszkolnej i wczesnoszkolnej z rozwijaniem zainteresowań i pozytywnych postaw wobec muzyki:

Nauczyciel kształtuje w dzieciach miłość lub niechęć do muzyki [...].

Zadaniem nauczyciela jest zapoczątkowanie zainteresowania muzyka wśród jego wychowanków.

Zadaniem nauczyciela jest zainteresowanie dziecka muzyka i rozbudzenie chęci do rozwijania swoich zainteresowań $i$ pasji w tym kierunku.

Wiele respondentek podkreślało związek między rozbudzaniem zainteresowań i pozytywną postawą dziecka wobec muzyki a odpowiednią wiedzą i umiejętnościami nauczyciela:

Nauczyciel w edukacji przedszkolnej $i$ wczesnoszkolnej jest pierwsza $i$ często jedyna osoba, która wprowadza dziecko w świat muzyki. Od tego, w jaki sposób to zrobi i z jakim stopniem przygotowania podejdzie do tematu, zależeć będzie późniejszy stosunek dzieci do muzyki; 
Tabela 1. Oceń odpowiedzialność nauczyciela edukacji przedszkolnej i wczesnoszkolnej w zakresie edukacji muzycznej:

\begin{tabular}{|l|c|}
\hline Kategorie & Liczba osób \\
\hline Bardzo wysoka & 14 \\
\hline Wysoka & 21 \\
\hline Przeciętna & 9 \\
\hline Niska & 2 \\
\hline Bardzo niska & 1 \\
\hline Razem: & 47 \\
\hline
\end{tabular}

Opracowanie własne.

Tabela 2. Jaką odpowiedzialność w zakresie edukacji muzycznej ma nauczyciel edukacji przedszkolnej i wczesnoszkolnej?

\begin{tabular}{|l|c|}
\hline $\begin{array}{l}\text { Kategorie wyodrębnione w wypowiedziach studentów. } \\
\text { Nauczyciel odpowiada za: }\end{array}$ & $\begin{array}{c}\text { Liczba } \\
\text { wskazań }\end{array}$ \\
\hline - rozwój muzyczny w okresie szczególnej podatności na oddziaływania muzyczne & 10 \\
\hline - rozwijanie zainteresowań i pozytywnych postaw wobec muzyki & 15 \\
\hline - wprowadzenie w świat muzyki, kultury muzycznej & 6 \\
\hline - przekazanie wiedzy z zakresu edukacji muzycznej & 11 \\
\hline - umiejętności muzyczne & 9 \\
\hline - uwrażliwianie dzieci na muzykę & 6 \\
\hline - świadomy odbiór muzyki & 1 \\
\hline - świadomość i ekspresję kulturowa & 1 \\
\hline - kompetencje muzyczne własne i ucznia & 1 \\
\hline Razem: & 60 \\
\hline
\end{tabular}

Opracowanie własne.

Nauczyciel posiada dużą odpowiedzialność w zakresie edukacji muzycznej, ponieważ dzięki przekazywanej wiedzy $i$ umiejętnościom może zaszczepić w dzieciach chęć poznania muzyki bardziej oraz uwrażliwiać ich na jej piękno;

Nauczyciel edukacji przedszkolnej $i$ wczesnoszkolnej jest odpowiedzialny za edukacje muzyczna dziec$k a$. W czasie, gdy dziecko najbardziej pragnie wiedzy, nauczyciel ma szansę rozbudzić w nim ciekawość $i$ zainteresowanie muzyka. Niewykorzystanie tej szansy może spowodować brak wiedzy $i$ podstawowych umiejętności z zakresu muzyki. Ważne jest więc, aby nauczyciel od początku rozbudzat $w$ dziecku chęć poznania muzyki. Inaczej, tak jak w moim przypadku, dziecko będzie miato braki w edukacji muzycznej.

W wypowiedziach niektórych respondentek zwrócono szczególną uwagę na odpowiedzialność nauczyciela w zakresie wprowadzania aktywności muzycznych, np.: 
Nauczyciel edukacji przedszkolnej $i$ wczesnoszkolnej jest odpowiedzialny m.in. za rytm, poprawna naukę śpiewu, naukę poprawnego wydobywania dźwięków, grę na instrumencie, wspótprace itd.

Uważam, że nauczyciel edukacji przedszkolnej i wczesnoszkolnej bierze odpowiedzialność za każdy zakres tematyczny podejmowany w trakcie zajęć, w tym edukacji muzycznej. [...] Ukazanie różnych form aktywności muzycznej pokazuje dzieciom/uczniom wiele aspektów z zakresu muzyki, których dzieci nie maja okazji poznać poza szkota/przedszkolem. Myśle też, ze edukacja muzyczna wplywa na ksztattowanie upodobań wobec muzyki, pozwala wydobyć z dziecka/ucznia to, co najlepsze.

Respondentki wykazały się także świadomością tego, że rozwój muzyczny dziecka w okresie przedszkolnym i wczesnoszkolnym odbywa się w momencie szczególnej podatności na oddziaływania muzyczne:

Zapoznawanie dzieci/uczniów z odpowiednim repertuarem muzyki, tzn. dostosowanym do ich wieku, poziomu możliwości, rozwoju, jest w stanie wpłynąć na ich stuch oraz rozwój muzyczny.

Ankietowane łączyły odpowiedzialność nauczyciela w zakresie edukacji muzycznej z elementarną wiedzą muzyczną:

Nauczyciel posiada odpowiedzialność za to, aby dziecko znato i rozumiało podstawowe pojęcia $i$ terminy muzyczne.

Nauczyciel edukacji przedszkolnej i wczesnoszkolnej w zakresie edukacji muzycznej odpowiada za zbudowanie u dzieci podstaw wiedzy muzycznej, umiejętności rozpoznawania dźwięków, rytmów, odpowiada za umuzykalnienie dzieci.

Jak wynika $z$ przeprowadzonych badań, respondentki są świadome doniosłości odpowiedzialności nauczyciela wynikającej z psychologicznych i pedagogicznych uwarunkowań procesu edukacji muzycznej. Optymistyczne jest to, że jako przyszłe nauczycielki łączą odpowiedzialność nauczyciela z rozwijaniem pozytywnym postaw i zainteresowań muzycznych, co jest zbieżne z postulatami takich pedagogów, jak m.in. M. Przychodzińska. Podkreślała ona:

[...] dążenie do budzenia i utrwalania tych zainteresowań i pozytywnych motywacji do muzyki powinno dominować na lekcjach tak dalece, że nauczyciel winien raczej zrezygnować doraźnie z precyzji wykonania zadania muzycznego niż dopuścić do zniechęcenia i zobojętnienia wobec muzyki. Sama muzyka oraz formy kontaktu $z$ nią i metody jej opanowania, powinny się dzieciom podobać, interesować swą różnorodnością, wywoływać radość i poznawczą ciekawość (Przychodzińska, Lipska, 1991, s. 7).

Wydaje się, że proces edukacji muzycznej akcentujący rolę zainteresowania i pozytywnych postaw dzieci będzie także korzystnie oddziaływał na stymulację uzdolnień, umiejętności, konstruowanie pojęć muzycznych, a w konsekwencji będzie wprowadzał dzieci do uczestnictwa w kulturze muzycznej. 


\section{Zakończenie}

Zarówno nauczyciel przedszkola, jak i klas I-III szkoły podstawowej, chcąc zadbać o prawidłowy i wszechstronny rozwój swoich uczniów, staje przed niełatwym zadaniem - powinien wspierać swoich wychowanków w ich działaniach, ale pamiętać także o ogromnej odpowiedzialności, która wiąże się z wychowaniem i nauczaniem. Jedną z dziedzin niezwykle ważnych jest edukacja muzyczna, która łączy się różnymi aktywnościami i pojęciami muzycznymi. Są to zagadnienia wymagające od nauczyciela wiedzy, umiejętności, a także świadomości. Tylko prawidłowe wspieranie rozwoju dziecka będzie skutkowało w przyszłości m.in. melodyjną mową, pięknym śpiewem, a także świadomym uczestnictwem w kulturze muzycznej. Odpowiedzialność, którą niesie edukacja muzyczna dzieci, to zadanie dla nauczycieli, mających we współczesnym pokoleniu ludzi niewrażliwych na piękno muzyki wychowywać prawdziwych jej miłośników.

\section{Bibliografia}

Bogdanowicz, M. (2001). Ruch i piosenka dla najmtodszych. Gdańsk: Focuss.

Bonna, B. (2016). Zdolności i kompetencje muzyczne uczniów w młodszym wieku szkolnym. Bydgoszcz: UKW.

Burowska, Z., Głowacka, E. (2006). Psychodydaktyka muzyczna. Zarys problematyki. Kraków: AM.

Frołowicz, E. (2012). Aktywność muzyczna a zmiany rozwojowe dziecka. Studium z obszaru wczesnoszkolnej edukacji muzycznej. Gdańsk: Wyd. AM.

Gordon, E. E. (1997). Umuzykalnianie niemowląt i małych dzieci. Teoria i wskazówki praktyczne. [Przeł. E. Kuchtowa, A. Zielińska]. Kraków: „Zamiast Korepetycji”.

https://sjp.pwn.pl/sjp/;2493511

Kisiel, M. (2005). Muzyka w świetle programów nauczania dla klas początkowych. W: tenże, Muzyka w zintegrowanej edukacji wczesnoszkolnej. Studium metodyczno-badawcze. Katowice: Wyd. UŚ.

Ławrowska, R. (2003). Uczeń i nauczyciel w edukacji muzycznej. Kraków: Wyd. AM.

Manturzewska, M. (1987). Dotychczasowe badania nad rozwojem muzycznym człowieka. W: Z. Burowska, E. Głowacka (red.), Z zagadnień zdolności, percepcji i kształcenia muzycznego. Materiaty II Konferencji Psychologów Pracujących w Szkolnictwie Wyższym. Kraków: AM. Katedra Wychowania Muzycznego.

Patzlaff, R. (2008). Zastygłe spojrzenie. Fizjologiczne skutki patrzenia na ekran a rozwój dziecka. Przeł. B. Kowalewska. Kraków: Impuls.

Przychodzińska, M., Lipska, E. (1991). Muzyka w nauczaniu poczatkowym. Metodyka. Warszawa: WSiP.

Rozporządzenie Ministra Edukacji Narodowej z dnia 14 lutego 2017 r. w sprawie podstawy programowej wychowania przedszkolnego oraz podstawy programowej kształcenia ogólnego dla szkoły podstawowej, w tym dla uczniów z niepełnosprawnością intelektualną w stopniu umiarkowanym lub znacznym, kształcenia ogólnego dla branżowej szkoły I stopnia, kształcenia ogólnego dla szkoły specjalnej przysposabiającej do pracy oraz kształcenia ogólnego dla szkoły policealnej. DzU, 2017, poz. 356. 
Sacher, W. A. (2012). Pedagogika muzyki. Teoretyczne podstawy powszechnego ksztatcenia muzycznego. Kraków: Impuls.

Sloboda J. (2002). Umyst muzyczny. Poznawcza psychologia muzyki. Warszawa: AM. Katedra Psychologii Muzyki.

Szubertowska, E. (2002). Muzyczna aktywność wtasna a świadoma percepcja muzyki młodzieży szkót średnich. Bydgoszcz: Wyd. Akademii Bydgoskiej.

Taraszkiewicz, M. (2001). Fak uczyć jeszcze lepiej. Szkoła petna ludzi. Poznań: Arka.

Trzos, P. A. (2018). Umiejętności audiacyjne uczniów na etapie edukacji wczesnoszkolnej. Bydgoszcz: Wyd. UKW.

Wilk, A. (1989). Metody kształcenia stuchu muzycznego dzieci w wieku szkolnym. Kraków: WSP. 